\title{
Model Pembelajaran Somatic, Auditory, Visualization, Intellectualy (SAVI) Berbantuan Icebreaker Terhadap Hasil Belajar IPA Siswa
}

\author{
I Kadek Peri Wijaya ${ }^{1 *}$, Gede Wira Bayu² ${ }^{2}$ Made Sumantri ${ }^{3}$ (D) \\ 1,2,3 Jurusan Pendidikan Dasar, Universitas Pendidikan Ganesha, Singaraja, Indonesia \\ *Corresponding author: periwijaya27@gmail.com
}

\begin{abstract}
Abstrak
Siswa yang kurang antusias dalam mengikuti pembelajaran baik secara individu maupun kelompok dan kurang mampunya guru dalam menerapkan model pembelajaran yang mampu menciptakan pembelajaran menarik dan menyenangkan. Tujuan penelitian adalah menganalisis model pembelajaran Somatic, Auditory, Visualization, Intellectualy (SAVI) berbantuan icebreaker terhadap hasil belajar IPA siswa kelas V. Penelitian ini merupakan penelitian semu dengan desain non-equivalent post-test only group design. Penelitian ini menggunakan populasi seluruh siswa kelas V SD yang berjumlah 128 orang. Berdasarkan tehnik random sampling dipatkan sampel sebagai kelompok eksperimen yaitu kelas V dengan jumlah siswa 25 orang dan kelompok kontrol yaitu kelas $\mathrm{V}$ dengan jumlah siswa 25 orang. Metode pengumpulan data yang digunakan adalah metode tes yaitu tes pilihan ganda yang berjumlah 30 butir soal. Data yang telah terkumpul kemudian diolah dengan statistik deskriptif dan inferensial. Berdasarkan hasil penelitian, diketahui bahwa rata-rata hasil belajar IPA yang diperolah kelompok eksperimen lebih besar jika dibandingkan dengan kelompok kontrol (18,34>15,78). Hasil uji-t menunjukkan thitung 3,598 dan tabel dengan taraf signifikansi 5\% didapatkan 2,021. Berdasarkan hasil pengujian thitung $>$ tabel $(3,598>2,021)$, sehingga Ho ditolak dan $\mathrm{H}_{1}$ diterima. Berdasarkan hasil penelitian, dapat disimpulkan bahwa terdapat pengaruh yang signifikan model pembelajaran Somatic, Auditory, Visualization, Intellectualy berbantuan icebreaker terhdap hasil belajar IPA siswa kelas V.
\end{abstract}

Kata kunci: SAVI, Icebreaker, IPA

\section{Abstract}

Students who are less enthusiastic in participating in learning both individually and in groups and the teacher's inability to apply learning models that can create interesting and fun learning. The purpose of the study was to analyze the Somatic, Auditory, Visualization, Intellectual (SAVI) learning model with the aid of an icebreaker on the science learning outcomes of class $V$ students. This study was quasi-research with a non-equivalent post-test-only group design. This study used a population of all students of class $V$, which amounted to 128 people. Based on the random sampling technique, the sample was assigned to the experimental group, namely class $V$ with 25 students, and the control group, namely class $V$ with 25 students. The data collection method used is the test method, namely a multiple-choice test, totaling 30 questions. The data that has been collected is then processed with descriptive and inferential statistics. Based on the results of the study, it is known that the average science learning outcomes obtained by the experimental group are greater than the control group (18.34>15.78). The results of the t-test showed tcount 3,598 and ttable with a significance level of 5\% obtained 2,021. Based on the test results tcount > ttable (3.598 > 2.021), so Ho is rejected and $\mathrm{HI}$ is accepted. So, it can be concluded that there is a significant effect of the Somatic, Auditory, Visualization, Intellectualy assisted learning model with the help of icebreaker on the science learning outcomes of fifth-grade students.

Keywords: SAVI, Icebreaker, Science

\section{INTRODUCTION}

Sains atau IPA adalah usaha manusia dalam memahami alam semesta melalui pengamatan yang tepat pada sasaran, serta menggunakan prosedur, yang dijelaskan dengan penalaran sehingga mendapatkan suatu kesimpulan (Putri et al., 2018; Zairmi et al., 2019). Pembelajaran IPA di SD hendaknya menimbulkan rasa ingin tahu karena setiap hari siswa mengalami kejadian yang terjadi langsung di alam. Pembelajaran IPA memiliki 3 bentuk praktikum yaitu latihan, investigasi dan pengalaman. Praktikum latihan bertujuan untuk mengembangkan keterampilan dasar, praktikum investigasi bertujuan mengembangkan kemampuan siswa memecahkan masalah yang dialami sehari-hari, praktikum pemberian pengalaman bertujuan untuk meningkatkan pemahaman siswa tentang kejadian disekitarnya.

\begin{tabular}{|c|c|c|}
\hline History: & & Publisher: Undiksha Press \\
\hline Accepted & : 12 Maret 2021 & (c) () () \\
\hline
\end{tabular}


Namun, berdasarkan hasil wawancara yang dilakukan dengan guru kelas V sekolah dasar di Gugus V Kecamatan Buleleng, diketahui bahwa nilai mata pelajaran IPA yang diperoleh siswa masih tergolong rendah, hal tersebut disebabkan oleh siswa yang kurang antusias dalam mengikuti pembelajaran baik secara individu maupun kelompok, siswa sering bercanda saat pelajaran, perbedaan kemampuan kognitif yang mengakibatkan pembelajaran tidak berlangsung sesuai dengan harapan. Selain itu guru juga cenderung menggunakan metode ceramah yang berdampak pada minat belajar siswa, guru juga tidak banyak mengenal dan memahami model pembelajaran inovatif. Nilai IPA ulangan tengah semester yang diperoleh siswa kelas V SD masih cenderung lebih banyak jumlah siswa yang memperoleh nilai di bawah KKM. Dari total 128 siswa kelas V SD hanya 54 orang yang nilainya sudah memenuhi KKM sedangkan 74 orang atau 58\% sisanya mendapat nilai di bawah KKM. Jika hal tersebut dibiarkan tanpa dilakukan sebuah solusi untuk perbaikan, akan memberikan dampak negative terhadap hasil pembelajaran. Solusi yang dapat diberikan terhadap permasalahan tersebut adalah dengan menerapkan model pembelajaran Somatic, Auditory, Visualization, Intellectualy (SAVI).

Somatic, Auditory, Visualization, Intellectualy (SAVI) adalah model pembelajaran dalam pendekatan pembelajaran Accelerated Learning atau cara belajar cepat dan alamiah, bermakna (Kusumantara et al., 2017; Murti et al., 2019). Model pembelajaran SAVI (Somatic, Auditory, Visualization, Intellectualy) merupakan salah satu dari tipe model pembelajaran kooperatif, pembelajaran yang melibatkan semua indera dalam aktivitas belajar. Model pembelajaran SAVI menuntut peserta didik melibatkan seluruh panca indera dalam pembelajaran, sehingga siswa lebih tertarik terhadap materi yang disampaikan akan berdampak pada hasil belajar siswa (Sulaksana et al., 2018; Yudiari et al., 2015; Yuliana \& Sisma, 2019). Pada penelitian ini, model pembelajaran SAVI akan lebih bermakna dan menarik jika dipadukan dengan icebreaker. Icebreaker merupakan sebuah teknik yang dimiliki oleh seorang guru untuk memecakan kebekuan. Kebekuan yang dimaksud adalah suasana kelas yang kurang menarik, suasana kelas yang kurang menarik akan berpengaruh pada fokus siswa untuk mengikuti pembelajaran (Arta et al., 2020; Satriani et al., 2018). Tujuan dari icebreaker sebagai penolong siswa untuk melakukan diskusi dengan cara meningkatkan kemampuan untuk berkomunikasi dan kerjasama team, dengan cara ini perbedaan budaya yang menjadi dinding pemisah antar siswa akan hilang dan akan menambah persahabatan antar siswa. Belum banyak penelitian yang mengkaji lebih dalam mengenai model pembelajaran SAVI berbantuan icebreaker di sekolah dasar.

Beberapa penelitian yang relevan dengan penelitian ini dilakukan oleh (Arta et al., 2020) menemukan bahwa terdapat pengaruh yang signifikan model pembelajaran Problem Based Learning berbantuan icebreaker terhadap kemampuan pemecahan masalah matematika siswa kelas IV SD. Kemudian penelitian lain menemukan bahwa model pembelajaran ARIAS dengan selingan icebreaker berpengaruh terhadap hasil belajar IPA siswa kelas V SD (Satriani et al., 2018). Penerapan model SAVI berpendekatan kontekstual tuntas baik individual maupun klasikal, kemampuan pemecahan masalah siswa pada kelas yang diajarkan model SAVI berpendekatan kontekstual lebih baik dari siswa yang diajarkan SAVI lebih baik dari siswa dengan pembelajaran konvensional (Taneo, 2017). Tujuan penelitian adalah menganalisis model pembelajaran Somatic, Auditory, Visualization, Intellectualy (SAVI) berbantuan icebreaker terhadap hasil belajar IPA siswa kelas V.

\section{MATERIALS AND METHODS}

Penelitian ini merupakan penelitian eksperimen semu (quasi experimental). Desain penelitian yang digunakan adalah non-equivalent post-test only control group design (Sugiyono, 2016). Populasi dalam penelitian adalah siswa kelas V Sekolah Dasar Gugus V 
Kecamatan Buleleng. Jumlah keseluruhan di Gugus V Kecamatan Buleleng yaitu 5 SD dengan 6 kelas di setiap SD. Jumlah siswa kelas V secara keseluruan adalah 128. Pengambilan dilakukan secara random, berdasarkan data yang diambil dari sampel maka sampel akan digeneralisasikan ke populasi asal dari sampel tersebut. Sebelum menentukan sampel penelitian, terlebih dahulu melakukan uji kesetaraan hasil belajar IPA siswa kelas V SD Gugus V kecamatan buleleng. Uji kesetaraan dilakukan menggunakan Analisis Varians Satu Jalur (Anava A). Dari lima sekolah dasar yang ada di Gugus V kecamatan buleleng, dilakukan dua pengudian. Setelah dilakukan pengundian didapat kelas V SDN 1 Petandakan sebagai kelompok eksperimen dan kelas V SDN 1 Nagasepaha sebagai kelompok kontrol. Sebaran jumlah siswa dari kelas esksperimen dan kelas kontrol yaitu kelas V SDN 1 Petandakan dengan jumlah 25 orang sebagai kelompok eksperimen yang dibelajarkan dengan Pembelajaran Somatic Auditory Vizualitation Intellectually (SAVI) berbantuan Icebreaker dan kelas V SDN 1 Nagasepaha dengan jumlah 25 orang sebagai kelompok kontrol dibelajarankan tanpa model pembelajaran Somatic, Auditory, Visualization, Intellectualy (SAVI) berbantuan Icebreaker. Metode pengumpulan yang digunakan berasal dari data hasil belajar menggunakan bentuk tes pilihan ganda. Teknik analisis yang digunakan ialah statistik deskriptif maka akan dilanjutkan dengan statistik inferensial. Setelah data yang diuji dengan uji prasyarat, jika terbukti bahwa kedua kelompok sampel berdistribusi normal dan homogen, maka pengujian selanjutnya adalah uji-t dengan rumus polled varian.

\section{RESULTS AND DISCUSSION}

Deksripsi data hasil penelitian memaparkan tentang data hasil belajar IPA kelompok eksperimen dan kelompok kontrol. Data hasil belajar IPA pada kelompok eskperimen yang diperoleh melalui post-test terhadap 25 orang siswa dan pada kelompok kontrol dengan jumlah 25 orang. Penelitian ini diperoleh mean $(\mathrm{M})$, median $(\mathrm{Md})$, modus $(\mathrm{Mo})$, varian, dan standar deviasi (Sd) dari data hasil belajar IPA kelompok eksperimen, yaitu: mean (M) $=18,34 ;$ median $(\mathrm{Md})=20 ;$ modus $(\mathrm{Mo})=10,78 ; \operatorname{varian}\left(\mathrm{s}^{2}\right)=6,88 ;$ dan standar deviasi $(\mathrm{Sd})$ $=2,62$. Setelah dikonversikan ke dalam kriteria penilaian skala lima, dapat dinyatakan bahwa rata-rata hasil belajar IPA kelompok eksperimen adalah $\mathrm{M}=18,34$ tergolong ke dalam kriteria tinggi yang berada pada rentangan 17,50 $\leq \bar{X}<22,50$. Sedangkan mean (M), median (Md), modus (Mo), varian, dan standar deviasi (Sd) dari data hasil belajar IPA kelompok kontrol, yaitu: mean $(\mathrm{M})=15,78$; median $(\mathrm{Md})=17$; $\operatorname{modus}(\mathrm{Mo})=11,61$; varian $(\mathrm{s} 2)=5,8$ dan standar deviasi $(\mathrm{Sd})=2,4$. Setelah dikonveri ke dalam kriteria skala lima, dapat diketahui bahwa rata-rata Hasil Belajar IPA kelompok kontrol adalah $\mathrm{M}=15,78$ yang berada pada rentangan $12,50 \leq \bar{X}<17,50$ dengan kategori sedang. Pengujian prasyarat dilakukan untuk mengetahui fakta apakah data memenuhi prasyarat uji normalitas dan uji homogenitas. Data yang diperoleh berdistribusi normal dan homogen sehingga hipotesis dianalisis menggunakan uji-t (pollend varian).

\section{Uji Normalitas}

Uji normalitas sebaran data dilakukan untuk meyakinkan bahwa sampel berasal dari populasi yang berdistribusi normal. Uji normalitas data untuk skor hasil belajar IPA diuji mebggunakan rumus Chi-Square $\left(\mathrm{X}^{2}\right)$ dengan kriteria, jika harga $\left(\mathrm{X}^{2}\right)$ hitung lebih kecil daripada $\left(\mathrm{X}^{2}\right)$ tabel pada taraf signifikansi 5\% dengan $\mathrm{dk}=$ (jumlah baris -1$)$ maka data berdistribusi normal. Uji normalitas data dilakukan terhadap hasil post-test pada kelompok eksperimen dan kelompok kontrol. Berdasarkan dari hasil perhitungan uji normalitas sebaran data dengan menggunakan bantuan Microsoft Excel 2019 for Wondows, uji normalitas sebaran data dengan rumus Chi-Square $\left(\mathrm{X}^{2}\right)$ dapat dilihat pada Tabel 1. Berdasarkan Tabel 1, diperoleh $\mathrm{X}^{2}$ hitung hasil post-test pada kelompok eksperimen sebesar 5,30. Sedangkan $\mathrm{X}^{2}$ hitung 
hasil post-test hitung hasil post-test pada kelompok kontrol sebesar 8,08 , dengan $\mathrm{dk}=$ jumlah baris $-1=6-1=5$, sehinnga didapat harga $X^{2}$ tabel sebesar 11,07. Hasil hitung tersebut menunjukkan bahwa $\mathrm{X}^{2}$ hitung hasil post-test pada kelompok eksperimen dan kelompok kontrol lebih kecil daripada $\mathrm{X}_{\text {tabel }}^{2}\left(\mathrm{X}^{2}\right.$ hitung $<\mathrm{X}_{\text {tabel }}^{2}$ ), sehingga dapat dinyatakan data yang diperoleh berdistribusi normal.

Tabel 1. Hasil uji normalitas sebaran data

\begin{tabular}{lcccc}
\hline No. & $\begin{array}{c}\text { Kelompok Data Hasil } \\
\text { Belajar IPA }\end{array}$ & $\mathbf{X}^{\mathbf{2}}$ & $\begin{array}{c}\text { Nilai Kritis pada Taraf } \\
\text { Signifikansi 5\% }\end{array}$ & Status \\
\hline 1 & Eksperimen & 5,30 & 5,99 & Normal \\
2 & Kontrol & 5,27 & 5,99 & Normal \\
\hline
\end{tabular}

\section{Uji Homogenitas varians}

Tujuan uji homogenitas varians untuk mencari tingkat homogenitas kelompok eksperimen dan kelompok kontrol. Rumus yang digunakan untuk menguji homogenitas varians kedua kelompok adalah rumus uji Fisher $(F)$ dengan kriteria data homogen jika $F_{\text {hitung }}$ $<\mathrm{F}_{\text {tabel }}$ pengujian pada taraf signifikansi 5\% dengan derajat kebebasan untuk pembilang dk1= $\mathrm{k}-1$ dan derajat kebedasan untuk pengebut $\mathrm{dk} 2=\mathrm{n}-\mathrm{k}$. Berdasarkan dari hasil perhitungan uji homogenitas varians dengan menggunakan bantuan Microsoft Excel 2019 for Wondows. Hasil uji homogenitas varians dengan Uji-F dapat dilihat pada Tabel 2. Berdasarkan Tabel 2, dapat diketahui bahwa $F_{\text {hitung }}$ skor hasil Belajar IPA kelompok eksperimen dan kontrol adalah 2,987 sedangkan $\mathrm{F}_{\text {tabel }}$ dengan taraf signifikasnis 5\% adalah 3,841. Hal ini menunjukkan bahwa, varian data hasil belajar IPA Kelompok eksperimen dan kontrol adalah Homogen.

Tabel 2. Hasil Uji Homogenitas dengan Uji F

\begin{tabular}{llccl}
\hline $\begin{array}{l}\text { Kelompok } \\
\text { Hasil Belajar IPA }\end{array}$ & Varians & F hitung & $\begin{array}{l}\text { Ftabel dengan Taraf } \\
\text { Signifikansi 5\% }\end{array}$ & Status \\
\hline $\begin{array}{l}\text { Eksperimen } \\
\text { Kontrol }\end{array}$ & $\begin{array}{l}6,88 \\
5,8\end{array}$ & 2,987 & 3,841 & Homogen \\
\hline
\end{tabular}

\section{Uji Hipotesis}

Berdasarkan uji normalitas sebaran data dan uji homogentias varians diperoleh bahwa hasil belajar IPA data dari kelompok eksperimen dan kelompok kontrol berdistribusi normal dan bersifat homogen. Setelah Uji prasyarat terpenuhi maka dilanjutkan dengan pengujian hipotesis, rumus yang digunakan adalah uji-t (polled varians). Karena $\mathrm{n} 1 \neq \mathrm{n} 2$ dan varians homogen, maka $\mathrm{db}=(\mathrm{n} 1+\mathrm{n} 2)-2$ dengan kriteria pengujian $\mathrm{H}_{0}$ ditolak jika $t_{\text {hitung }}>\mathrm{t}_{\text {tabel }}$ dan $\mathrm{H}_{0}$ diterima $\mathrm{t}_{\text {hitung }}<\mathrm{t}_{\text {tabel }}$. Hasil uji-t dapat dilihat pada Tabel 3. Berdasarkan Tabel 4, tampak bahwa thitung sebesar 3,594, sedangkan $t_{\text {tabel dari }} \mathrm{dk} 48$ pada taraf signifikansi $5 \%$ adalah 2,021. Hal ini berarti, $t_{\text {hitung }}$ lebih besar dari $\mathrm{t}_{\text {tabel }}\left(\mathrm{t}_{\text {hitung }}>\mathrm{t}_{\text {tabel }}\right)$, sehingga $\mathrm{H}_{0}$ ditolak dan $\mathrm{H}_{1}$ diterima. Jadi terdapat perbedaan yang signifikan hasil belajar IPA antara kelompok siswa yang mengikuti pembelajaran dengan menggunakan model pembelajaran SAVI berbantuan Icebreaker dan kelompok siswa yang tidak mengikuti pembelajaran dengan menggunakan model pembelajaran SAVI berbantuan Icebreaker pada kelas V SD.

Tabel 3. Hasil Analisi Uji-t

\begin{tabular}{lllllll}
\hline Kelompok & $\mathbf{n}$ & $\mathbf{d b}$ & Mean $(\overline{\boldsymbol{X}})$ & $\mathbf{S}^{\mathbf{2}}$ & $\mathbf{t}_{\text {hitung }}$ & $\mathbf{t}_{\text {tabel }}$ \\
\hline Eksperimen & 25 & \multirow{2}{*}{48} & 18,23 & 6,88 & \multirow{2}{*}{3,59} & 2,02 \\
Kontrol & 25 & & 15,78 & 5,8 & \\
\hline
\end{tabular}




\section{Pembahasan}

Berdasarkan hasil pengujian hipotesis dengan uji-t menunjukkan bahwa terdapat pengaruh signifikan model pembelajaran SAVI berbantuan Icebreaker terhadap hasil belajar IPA pada kelas V SD Gugus V Kecamatan Buleleng Tahun Pelajaran 2019/2020. Selama pelaksanaan penelitian pada kelas V SD Gugus V Kecamatan Buleleng khususnya pada kelompok eksperimen berjalan dengan optimal dan efektif. Sebelum diberikan treatment hasil belajar yang diperoleh oleh kelompok eksperimen dan kelompok kontrol setara. Namun setelah diberikan treatment pada kelompok eksperimen terdapat perbedaan hasil belajar IPA. Rata-rata skor hasil belajar kelompok eksperimen lebih tinggi dari kelompok kontrol. Selain itu, beberapa hal yang menjadi alasan keberhasilan penerapan model pembelajaran Somatic, Auditory, Visualization, Intellectualy (SAVI) berbantuan icebreaker adalah sebagai berikut.

Pertama, secara kasat mata siswa lebih tertarik dan aktif dalam pembelajaran. saat pembelajaran berlangsung siswa terlihat antusias untuk berpartisipasi. Partisipasi dari setiap siswa menimbulkan persaingan yang ketat antar siswa yang satu dan yang lainnya, sehingga setiap siswa akan merespon dan memecahkan masalah yang dihadapi serta bertanggungjawab atas pencapaiannya dalam proses pembelajaran. Hal ini tentu dikarenakan dalam model pembelajaran SAVI mampu mengembangkan kesadaran siswa dan kemampuan untuk mengaplikasikan pengetahuan mereka pada konteks yang lebih kompleks, mengintegrasikan pengetahuan dengan sikap pribadi mereka dan nilai kemudian membangun personalitas mereka dan kemampuan profesional. Siswa juga aktif dalam menggunakan aktivitas fisiknya dalam bergerak dan berpartisipasi aktif di dalam proses pembelajaran. Hal ini dikarenakan terdapat unsur somatic dalam model pembelajaran SAVI. Somatic artinya Ketika dalam proses pembelajaraan siswa ikut bergerak dan bangkit dari tempat duduk dan bertindak aktif secara fisik selama proses belajar. Dalam hal ini berarti siswa berdiri dan bergerak kesana kemari meningkatkan sirkulasi dalam tubuh dan oleh karena itu mendatangkan energi segar ke dalam otak. Belajar somatis ini bias terhadap tubuh dimana anak-anak yang bersifat somatis, yang tidak dapat duduk tenang dan harus menggerakkan tubuh mereka untuk membuat pikiran mereka tetap hidupHasil penelitian ini didukung oleh penelitian yang menemukan bahwa pembelajaran SAVI dapat meningkatkan partisipasi dan aktivitas belajar siswa (Kencanawati et al., 2020; Setiadi, 2016).

Temuan kedua, timbul keberanian siswa untuk bertanya atau mengemukakan pendapat dengan teman ataupun guru. Hal ini dikarenakan dalam model pembelajaran SAVI terdapat unsur auditory. Belajar auditory ini berarti menekankan pada aspek keterampilan berbicara dan menyimak. Sehingga ketika dalam proses pembelajaran pun seorang guru harus memberikan ruang pada peserta didik untuk meluapkan pendapatnya yang tertampung dalam otak mereka (Cantona \& Sudarma, 2020; Kusumaningsih et al., 2019). Dimulai dari keberanian siswa untuk bertanya yang mana akan melatih keterampilan siswa dalam berkomunikasi. Dengan adanya respon dari siswa berupa pertanyaan akan menimbulkan komunikasi yang ideal antara siswa dengan siswa dan siswa dengan guru. Hal tersebut tentu akan membuat siswa mendapatkan pengetahuan baru yang belum mereka pahami. Selain itu siswa juga mendapat informasi yang pasti baik dari siswa lain atupun dari guru. Selain itu, selama pemebelajaran berlangsung timbul kesan senang untuk mengikuti pemebelajaran. Kesan senang menjadikan siswa lebih antusias mengikuti pembelajaran dikelas, selain itu kesan senang juga mematahkan perspektif siswa tentang pembelajaran IPA yang rumit dan membosankan. Rasa senang juga dapat menajdi motivasi tersendiri bagi siswa untuk belajar yang didasari atas ketertarikan. Kesan senang yang dirasakan oleh siswa merupakan hasil dari perpaduan antara model pembelejaran SAVI dengan Icebreaker. selain model pembelajaran SAVI yang memberikan siswa pengalaman dalam hal mengenal, memahami dan menerapkan berbagai informasi melalui belajar yang sistematis dan bermakna dalam mengkontruksikan materi yang sedang dipelajari. Sedangkan dengan adanya icebreaker akan memecahkan 
kesuntukan siswa saat belajar sehingga setiap siswa merasa jenuh ataupun lelah saat belajar. Hasil penelitian ini didukung oleh temuan penelitian yang menyatakan bahwa dengan penerapan icebreaker, akan tercipta suasana pembelajaran lebih santai dan menyenangkan (Arta et al., 2020; Satriani et al., 2018).

Temuan ketiga yaitu terdapat peningkatan hasil belajar IPA dengan menggunakan model pembelajaran SAVI berbantuan icebreaker. Hal ini dikarenakan model pembelajaran yang diterapkan mampu memberikan siswa kesempatan untuk lebih mengeksplorasi dan membangun sendiri pengetahuannya. Selain itu, siswa akan terlatih untuk mampu menyelesaikan masalah yang akan dihadapi dikemudian hari. Peningkatan ini diharapkan pengaruh dari pengetahuan yang diperoleh siswa diharapkan bukan dari hasil mengingat, tetapi dari pengalaman yang didapat siswa dari proses pembelajaran serta penjelasan materi yang disampaikan melalui tutor sebaya. Peningkatan hasil belajar di samping aspek kognitif juga mampu meningkatkan aspek afektif dan psikomotorik. Aspek afektif yang tampak dari hasil observasi aktivitas siswa. Sedangkan aspek psikomotorik dapat dilihat dari kecepatan dan ketepatan siswa dalam menyelesaikan tugas. Hasil penelitian ini didukung oleh temuan penelitian yang menemukan bahwa model pembelajaran SAVI berpengaruh positif terhadap hasil belajar IPA (Satriani et al., 2018; Yulandra \& Pujiastuti, 2018). Implikasi penggunaan model pembelajaran SAVI berbantuan icebreaker, yaitu siswa merasa tertarik dan aktif berpartisipasi juga merasa berani dalam mengemukakan pendapat sehingga mampu meningkatkan semangat dan fokus dalam dalam mengikuti pembelajaran. Selain itu, pembelajaran SAVI berbantuan icebreaker juga melatih siswa dalam memecahkan masalah

\section{CONCLUSION}

Terdapat pengaruh yang signifikan model pemebelajaran SAVI berbantuan icebreaker terhadap hasil belajar IPA pada kelas V SD. Model pembelajaran SAVI dapat digunakan sebagai salah satu alternatif model pembelajaran untuk meningkatkan atau mengembangkan kemampuan berpikir siswa. Disarankan kepada guru agar mampu menerapkan model pembelajaran inovatif lainnya agar siswa tidak mudah merasa bosan.

\section{REFERENCES}

Arta, I. M., Japa, I. G. ., \& Sudarma, I. K. (2020). Problem Based Learning Berbantuan Icebreaker Berpengaruh Terhadap Kemampuan Pemecahan Masalah Matematika. Mimbar PGSD Undiksha, 8(2), 264-272. http://dx.doi.org/10.23887/jjpgsd.v8i2.25435.

Cantona, I. G. E., \& Sudarma, I. K. (2020). Model Pembelajaran SAVI Berbantuan Media Mind Mapping Meningkatkan Hasil Belajar IPA Siswa Kelas V. Jurnal Pedaagogi Dan Pembelajaran, 3(2), 269-279. http://dx.doi.org/10.23887/jp2.v3i2.26615.

Kencanawati, S. A. M. M., Sariyasa, S., \& Hartawan, I. G. N. Y. (2020). Pengaruh penerapan model pembelajaran SAVI (Somatic, Auditory, Visual, Intellectual) terhadap kemampuan berpikir kreatif matematis. Pythagoras: Jurnal Pendidikan Matematika, 15(1), 13-23. https://doi.org/10.21831/pg.v15i1.33006.

Kusumaningsih, W., Sutrisno, S., \& Hidayah, F. (2019). Efektivitas Model Pembelajaran Savi dan React Berbantuan LKS terhadap Kemampuan Komunikasi Matematis Siswa SMP. Journal of Medives: Journal of Mathematics Education IKIP Veteran Semarang, 3(2), 197. https://doi.org/10.31331/medivesveteran.v3i2.763.

Kusumantara, K. S., Santyadiputra, G. S., \& Sugihartini, N. (2017). Pengaruh E-Learning Schoology Terhadap Hasil Belajar Simulasi Digital Dengan Model Pembelajaran SAVI. Jurnal Pendidikan Teknologi Dan Kejuruan, 14(2), 126-135. 
https://doi.org/10.23887/jptk-undiksha.v14i2.10387.

Murti, E. D., Nasir, N., \& Negara, H. S. (2019). Analisis Kemampuan Pemecahan Masalah Matematis: Dampak Model Pembelajaran SAVI ditinjau dari Kemandirian Belajar Matematis. Desimal: Jurnal Matematika, 2(2), 119-129. https://doi.org/10.24042/djm.v2i2.4072.

Putri, N. M. C. D., Ardana, I., \& Agustika, G. N. S. (2018). Pengaruh Model Discovery Learning Berbantuan Lingkungan Terhadap Kompetensi Pengetahuan IPA Siswa Kelas V. International Journal of Elementary Education, 2(3), 211. https://doi.org/10.23887/ijee.v2i3.15960. .

Satriani, N. M. P., Pudjawan, K., \& Suarjana, I. M. (2018). Pengaruh Model Pembelajaran Arias dengan Selingan Ice Breaker terhadap Hasil Belajar IPA. Jurnal Ilmiah Sekolah Dasar, 2(3), 312-320. https://doi.org/http://dx.doi.org/10.23887/jisd.v2i3.16147

Setiadi, H. W. (2016). Pengaruh Model Pembelajaran Savi Berbasis Multimedia Terhadap Minat Dan Prestasi Belajar Mahasiswa Pada Mata Kuliah Media Pembelajaran. Elementary School, 3(1), 216-226. https://doi.org/10.31316/esjurnal.v3i2.579.

Sugiyono. (2016). Metode Penelitian Kualitatif, Kuantitatif, dan R\&D. Alfabeta.

Sulaksana, Y. T., Margunayasa, I. G., \& Wibawa, I. M. C. (2018). Pengaruh Model Pembelajaran SAVI (Somatic Auditory Visualization Intellectualy) Berbantuan LKS terhadap Hasil Belajar IPA. Jurnal Pedaagogi Dan Pembelajaran, 1(3). http://dx.doi.org/10.23887/jisd.v3i3.18895.

Taneo, P. N. L. (2017). Pembelajaran Model SAVI Berpendekatan Kontekstual Terhadap Kemampuan Pemecahan Masalah Matematika Siswa. JPMI (Jurnal Pendidikan Matematika Indonesia), 1(1), 14. https://doi.org/10.26737/jpmi.v1i1.77.

Yudiari, M. M., Parmiti, D. P., \& Sudana, D. N. (2015). Pengaruh Model Pembelajaran SAVI Berbantuan Media Mind Mapping Terhadap Hasil Belajar IPA Siswa Kelas V. MIMBAR PGSD Undiksha, 3(1). http://dx.doi.org/10.23887/jjpgsd.v3i1.5683.

Yulandra, R., \& Pujiastuti, P. (2018). Penerapan Model Pembelajaran Stad Dan Savi Untuk Meningkatkan Hasil Belajar Ipa Siswa Kelas V Mandurian Kabupaten Tapin Kalimantan Selatan. Jurnal Ilmiah Didaktika, 19(1), 107-123. http://dx.doi.org/10.22373/jid.v19i1.4197.

Yuliana, D., \& Sisma, R. U. A. (2019). Penerapan Model Pembelajaran Savi (Somatis, Auditori, Visual, Dan Intelektual) Untuk Meningkatkan Minat Dan Hasil Belajar Peserta Didik. Jurnal Pendidikan Dan Kewirausahaan, 7(1). https://doi.org/10.47668/pkwu.v7i1.19.

Zairmi, U., Fitria, Y., \& Amini, R. (2019). Penggunaan Model Pembelajaran Two Stay Two Stray Dalam Pembelajaran IPA Di Sekolah Dasar. Jurnal Basicedu, 3(4), 1031-1037. https://doi.org/10.31004/basicedu.v3i4.221. 